\title{
ANALISIS PENENTUAN PRIORITAS PENGENDALIAN LOGISTIK BENCANA DI SULAWESI TENGAH
}

\author{
MOH. APRIAWAN \\ H. MUH. FAISAL \\ SURYADI HADI \\ Jurusan Manajemen Fakultas Ekonomi Universitas Tadulako \\ Email: aphinkapriawan@gmail.com
}

\begin{abstract}
This research aims to identify factors that affect disaster logistics control in Central Sulawesi and factors that become priority in disaster logistics control in Sulawesi Tengah. The respondents of this research are officials in Disaster Management Agency and Social Services Department of Central Sulawesi. This research uses the Analytical Hierarchy Process (AHP) method to portray the factors that affect the disaster logistics handling in Sulawesi Tengah in more detail. Data collection is done with in-depth interview and questionnaires distributed to the four samples. Sampling technique is purposive sampling or judgmental sampling. The data is processed using the Microsoft Office Excel 2007. Based on the analysis, it is shown that: there are five factors that affect disaster logistics handling in Central Sulawesi; (1) human resource, (2) uncertainty, (3) collaboration and cooperation, (4) facility, and (5) funding. Human resource is the priority factor in disaster logistics handling in Central Sulawesi with 0.6 point, whereas training is the main factor that affects the quality of human resource with 0.8 point.
\end{abstract}

Keywords: Disaster, AHP, Logistics, Victim, Priority.

\section{ABSTRAK}

Penelitian ini bertujuan untuk mengetahui faktor-faktor yang mempengaruhi Pengendalian Logistik Bencana di Sulawesi Tengah serta untuk mengetahui faktor yang menjadi Prioritas Pengendalian Logistik bencana di Provinsi Sulawesi Tengah. Badan Penanggulangan Bencana Daerah (BPBD) Provinsi Sulawesi Tengah serta Dinas Sosial Provinsi Sulawesi Tengah menjadi tempat pengambilan responden dalam penelitian ini. Penelitian ini akan memecahkan permasalahan yang akan diteliti dengan menggunakan metode Analytical Hierarchy Process (AHP) sehingga dapat menggambarkan faktor-faktor yang berpengaruh terhadap penanganan logistik bencana di Provinsi Sulawesi Tengah secarah lebih detail. Pengumpulan data dilakukan dengan cara wawancara mendalam dan menyebarkan kuesioner ke empat orang sampel. Tehnik dalam penarikan sampel menggunakan tehnik purposive sampling atau judgemental sampling. Data yang telah terkumpul diolah dengan menggunakan alat pengolahan angka Microsoft office excel 2007. Berdasarkan hasil analisis menunjukan bahwa: terdapat 5 kriteria yang mempengaruhi penanganan logistik bencana di Provinsi Sulawesi Tengah yaitu; (1) Sumber Daya Manusia, (2) Ketidakpastian, (3) Kolaborasi dan Kerjasama, (4) Sarana Prasarana, dan (5) Pendanaan. Dari kelima Faktor ini sumber daya manusia adalah prioritas utama dalam penanganan logistik bencana di Provinsi Sulawesi Tengah dengan bobot 0,6 dimana pelatihan adalah faktor utama yang mempengaruhi kualitas sumber daya manusia dengan bobot 0,8.

Kata Kunci: Bencana, AHP, Logistik, Korban, Prioritas.

\section{PENDAHULUAN}

Bencana Gempa Bumi yang terjadi di Pidie Jaya yang guncangannya dirasakan se Santereo Aceh pada Rabu, 7 Desember 2016 itu menelan korban baik jiwa maupun materil yang cukup banyak. Kondisi Serupa pun pernah terjadi di Provinsi Aceh. Bahkan lebih parah lagi Bencana Gempa yang kemudian disusul Tsunami di Aceh, 26 Desember 2004 silam memakan korban kurang lebih 200 ribuan jiwa meninggal, ribuan luka-luka, serta kerugian materil mencapai Rp42,7 Triliun yang mana menguras hampir 92 persen PDB Aceh. Hampir semua sarana transportasi tadak ada yang bisa digunakan, sehingga sampai keesokan harinya rombongan Presiden RI ke-6 Susilo Bambang Yudoyono yang ingin meninjau lokasi pun hanya bisa mendaratkan pesawatnya di Bandar Udara Medan, karena Bandar udara Aceh yang lumpuh total. 
Pasca terjadi bencana penderitaan warga Aceh belum berakhir, pasalnya logistik bantuan belum banyak yang bisa mereka dapatkan akibat kondisi insfrastruktur kota yang lumpuh total. Keterlambatan pemberian bantuan dan penanganan kondisi pasca bencana Tsunami Aceh ini setidaknya menambah penderitaan rakyat Aceh.

Indonesia memang negara yang berada diantara pertemuan tiga lempeng tektonik dunia sehingga sangat rentang akan bencana alam. Akibat itu juga Indonesia memiliki 128 gunung berapi aktif, sungai-sungai besar dan kecil yang melintasi wilayah padat penduduk serta potensi lautan lepas yang sewaktu-waktu bisa menimbulkan gelombang tsunami seperti yang terjadi di Aceh 2004 Silam.

Menurut Undang-Undang No. 24 tahun 2007, bencana merupakan kejadian yang dapat menyebabkan kerugian terhadap kehidupan dan penghidupan masyarakat, baik korban jiwa manusia, kerusakan lingkungan, kerugian harta benda, dan dampak psikologis. Ancaman, kerentanan, dan kemampuan yang di picu oleh suatu kejadian merupakan faktor yang menyebabkan bencana dapat terjadi (BPBN, 2012). Oleh karena itu, jika faktor-faktor tersebut dapat diminimisasi, maka hal ini dapat mencegah terjadinya bencana yang dapat mengganggu kehidupan masyarakat Indonesia.

Berdasarkan kategori jenis bencana yang dapat terjadi di Indonesia dapat disebabkan oleh beberapa faktor (BPBN, 2012), antara lain:

1) Faktor geologis, misalnya:gempa bumi, tsunami, letusan gunung berapi.

2) Faktor hydro meteorologis, misalnya: banjir, tanah longsor, kekeringan, dan angin topan.

3) Faktor biologis, misalnya: wabah penyakit, penyakit tanaman, penyakit ternak, dan Hama tanaman.

4) Faktor kegagalan tekhnologi, misalnya: kecelakaan industry dan transportasi, radiasi nuklir, dan pencemaran bahan kimia.

5) Faktor sosial politik, misalnya: konflik horizontal, terorisme, ideologi, dan religi.

Sulawesi Tengah sendiri merupakan provinsi yang memiliki pegunungan, daratan tinggi, sungai, serta dataran rendah yang cukup luas. Luas wilayah daratan Provinsi Sulawesi Tengah adalah 68.033 $\mathrm{km}^{2}$ atau 35,96 persen dari luas Pulau Sulawesi dan Perairan Laut seluas 193.923,75 km². Secara geografis Provinsi Sulawesi Tengah terletak antara $2^{\circ} 22^{`}$ Lintang Utara dan $3^{\circ} 48^{`}$ Lintang Selatan serta $119^{\circ} 22^{`}$ dan $124^{\circ} 22^{`}$ Bujur Timur.

Data yang penulis dapatkan menjelaskan kondisi infrasturktur jalan Sulawesi Tengah yang belum layak sebesar 57 persen. Sementara itu, provinsi ini memiliki pelabuhan laut sebanyak 14 unit dan Bandar udara sebanyak 6 unit. Jika dilihat dari cakupan luas wilayah serta kondisi infrastruktur jalan, untuk bisa melakukan koordinasi dengan baik kepada semua pihak guna mempercepat penanganan bencana sangatlah sulit melihat kondisi yang ada sehingga pemerintah Sulawesi Tengah sebaiknya merencanakan sejak awal pengelolaan logistik bencana dengan baik sehingga respon terhadap korban menjadi lebih cepat.

Menurut Oktarina (2009) Logistik sendiri memiliki arti kegiatan yang mengkoordinasikan penyaluran barang dari titik asal ketitik tujuan sesuai dengan jenis, jumlah, waktu, dan tempat yang dikehendaki oleh konsumen. Kegiatan logistik bencana akan melibatkan beberapa pihak terkait yang dimulai dari pencarian sumber, pengadaan, jaminan kualitas, pengemasan, pengiriman, pengangkutan, penyimpanan, pengelolaan inventori, dana asuransi. Untuk itu, pengawasan sangat dibutuhkan agar bantuan bencana dapat disalurkan kepihak korban bencana.

Menurut Altay (2006) ada beberapa hal yang mempengaruhi koordinasi logistik bencana, antara lain; kebutuhan korban, keadaan yang tidak pasti, kualitas informasi, dan kompleksitas. Peristiwa bencana banjir bandang dan tanah longsonr di kabupaten Morowali silam dapat dijadikan acuan jika manajemen logistik bencana tidak dikelola dengan baik. Oleh karena itu, penelitian Altay menemukan bahwa penanganan logistik bencana sebaiknya memperhatikan beberapa faktor, antara lain; struktur fungsi operasional, kerjasama beberapa departemen terkait, strategi komunikasi darurat nasional, system logistik yang modern, fleksibel dan transparan, proses evakuasi, perencanaan komunikasi publik, koordinasi antar pihak terkait, menciptakan budaya siap terhadap bencana, meningkatkan kerjasama dengan LSM dan sukarelawan, mempersiapkan bantuan, melibatkan kontraktor swasta, memiliki system yang terintegrasi, mitigasi struktural, menggunakan global information system, koordinasi dengan daerah lain, dan informasi publik. Beberapa faktor tersebut di atas menjadi rujukan dalam penyusunan kajian manajemen logistik dan peralatan bencana ini.

Berdasarkan latar belakang masalah di atas maka tujuan dalam penelitian ini adalah untuk mengetahui Penentuan Prioritas Pengendalian Logostik Bencana di Sulawesi Tengah serta untuk 
mengetahui faktor-faktor yang paling dominan berpengaruh terhadap Penentuan Prioritas Pengendalian Logostik Bencana di Sulawesi Tengah.

\section{KAJIAN LITERATUR}

\section{Definisi Manajemen Logistik}

Menurut James R. Stock dan Douglas (2001) Manajemen logistik adalah bagian dari proses rantai supplay yang terencana, dapat diterapkan, dan efisiensi dalam pengontrolan, aliran yang efektif dan penyimpanan barang, jasa, dan informasi terkait dari titik-asal ke titik-konsumsi dalam rangka memenuhi kebutuhan pelanggan.

Menurut H. Subagya, MS (1996) Logistik merupakan salah satu kegiatan yang bersangkutan dengan segi-segi Perencanaan dan pengembangan, pengadaan, penyimpanan, pemindahan, penyaluran, pemeliharaan, pengungsian dan penghapusan alat-alat perlengkapan Pemindahan, pengungsian dan peralatan personil Pengdaan atau pembuatan, penyelengaraan pemeliharaan dan penghapusan fasilitas-fasilitas Pengusaha atau pemberian pelayanan / bantuan-bantuan.

Lukas Dwiantara dan Rumsari Hadi (2004) mendefinisikan Manajemen logistik sebagai serangkaian kegiatan perencanaan, pengorganisasian, dan pengawasan terhadap kegiatan pengadaan pencatatan, pendistribusian, penyimpanan, pemeliharaan dan penghapusan logistik guna mendukung efektivitas dan efidiensi dalam upaya pencapaian tujuan organisasi'.

Taufik Amir (2005) dalam bukunya "Dinamika Pemasaran" mendefinisikan manajemen sebagai sebuah proses perencanaan, pengorganisasian, pengkoordinasian, dan pengontrolan sumber daya untuk mencapai sasaran secara efektif dan efesien. Efektif berarti bahwa tujuan dapat dicapai sesuai dengan perencanaan, sementara efisien berarti bahwa tugas yang ada dilaksanakan secara benar, terorganisir, dan sesuai dengan jadwal.

Indriyi G dan Agus Mulyono (2000) mendefinisikan Kegiatan logistik sebagai kegiatan mengembangkan operasi yang terpadu dari kegiatan pengadaan atau pengumpulan bahan, pengangkutan atau transportasi, penyimpanan, pembungkusan maupun pengepakan pendistribusian, dan pengaturan terhadap kegiatan tersebut.

Berdasarkan difinisi yang dikemukakan para ahli diatas dapat simpulkan bahwa Manajemen Logistik merupakan serangkaian kegiatan mulai dari, perencanaan, pengorganisasian, pengkoordinsian, pengawasan, pada kegiatan pengadaan, pencatatan, penyaluran, pemindahan, penyimpatan sumberdaya guna mencapai tujuan yang diinginkan secara efektif dan efisien.

\section{Faktor-faktor utama dalam pengendalian logistik bencana}

Kemampuan organisasi yang bergerak dalam bidang kebencanaan dalam mengurangi pengaruh internal dan eksternal terhadap pelaksanaan manajemen logistik bencana akan berpengaruh kepada kurangnya dampak negatif yang ditimbulkan oleh bencana. Artinya, tingkat kesuksesan organisasi yang terlibat dalam pengaturan logistik bencana dapat diukur dari sejauh mana kemampuan organisasi dalam mengatur arus barang dan peralatan yang dibutuhkan korban.

Petit dan Beresford (2012) Menyebutkan bahwa faktor-faktor yang mempengaruhi pengendalian logistik bencana adalah adanya perencanaan strategis (strategic planning), manajemen persediaan (inventory management) yang baik, perencanaan transportasi (transport planning), perencanaan kapasitas (capacity planning), manajemen informasi (information management), manajemen sumberdaya manusia (human resource management), perbaikan terus menerus (continuousimprovement), kerjasama (collaboration), dan pemanfaatan teknologi (technology utilization).

Van Wassenhove (2006) Menyebutkan bahwa Sumber Daya Manusia, manajemen pengetahuan, operasional dan manajemen proses, sumber daya keuangan, dan komunitas adalah faktor-faktor utama yang mempengaruhi pengendalian logistik bencana.

Menurut Petit dan Beresford (2009) keputusan jangka panjang, perencanaan, manajemen persediaan, perencanaan transportasi, perencanaan kapasitas pergudangan, manajemen informasi, penerapan teknologi, dan perbaikan yang berkelanjutan serta adanya hubungan dengan suplier (kolaborasi) adalah faktor-faktor utama yang mempengaruhi manajemen logistik bencana.

Berdasarkan uraian diatas bisa disimpulkan secara garis besar ada 6 (enam) faktor utama yang dapat mempengaruhi logistik bencana yakni; Sumber Daya Manusia (SDM), Infrsatruktur, sarana prasarana, pendanaan, kolaborasi dan kerja sama dan situasi ketidak pastian. 


\section{Konsep Analytic Hierarchy Process (AHP)}

Metode proses hierarki analitik (AHP) pertama kali dikembangkan oleh Thomas L. Saaty ahli matematika dari University of Pitsburgh Amerika Serikat pada awal tahun 1970-an. Pengamatan mendasar tentang sifat manusia, pemikiran analitik dan pengukuran membawa pada pengembangan suatu model yang berguna untuk memecahkan persoalan secara kuantitatif. Proses hierarki analitik adalah suatu model yang luwes yang memberikan kesempatan bagi perorangan atau kelompok untuk membangun gagasan-gagasan dan mendefinisikan persoalan dengan cara membuat asumsi mereka masing-masing dan memperoleh pemecahannya yang diinginkan darinya. Proses ini juga memungkinkan orang menguji kepekaan hasilnya terhadap perubahan informasi. Dirancang untuk lebih menampung sifat alamiah manusia ketimbang memaksa kita ke cara berfikir yang mungkin justru berlawanan dengan hati nurani, AHP merupakan proses yang ampuh untuk menanggulangi berbagai persoalan yang kompleks (Saaty, 1993).

Proses Hierarki Analitik memberikan suatu kerangka. Kerangka ini memungkinkan kita untuk mengambil keputusan yang efektif atas persoalan kompleks dengan jalan menyederhanakan dan mempercepat proses pengambilan keputusan yang kita alami. Pada dasarnya, metode AHP ini memecah-mecahkan suatu situasi yang kompleks, tak terstruktur ke dalam bagian-bagian komponennya menata bagian atau variabel ini dalam suatu susunan hierarki. Melalui serentetan kerja matematis, AHP mensintesis penilaian-penilaian mereka menjadi suatu taksiran menyeluruh dari prioritas-prioritas relatif berbagai alternatif tindakan dengan memberikan nilai numerik pada pertimbangan subjektif tentang relatif pentingnya setiap variabel dan mensintesis berbagai pertimbangan ini untuk menetapkan variabel mana yang memiliki prioritas paling tinggi dan bertindak untuk mempengaruhi hasil pada situasi tersebut.

AHP dapat digunakan untuk merangsang timbulnya gagasan untuk melaksanakan kegiatan kreatif dan untuk mengevaluasi keefektifan tindakan tersebut. Selain itu untuk membantu para pemimpin menetapkan informasi apa yang patut dikumpulkan guna mengevaluasi pengaruh faktor-faktor relevan dalam situasi kompleks. AHP juga dapat melacak ketidakkonsistenan dalam pertimbangan dan preferensi peserta, sehingga para pemimpin mampu menilai mutu pengetahuan para pembantu mereka dan kemantapan pemecahan itu.

Adapun keunggulan metode AHP antara lain: 1) dapat memecahkan berbagai persoalan yang kompleks, 2) dapat digambarkan secara grafis sehingga mudah untuk dipahami oleh semua pihak yang terlibat dalam pengambilan keputusan, 3) dapat digunakan tanpa database, asalkan para analisis memahami dan menguasai secara mendalam permasalahan yang akan dipecahkan, dan 4) dapat menguji konsistensi penilaian sehingga bila terjadi penyimpangan dapat dilakukan perbaikan (Saaty, 1980).

\section{Prinsip Kerja AHP}

Pengambilan keputusan dalam metodologi AHP didasarkan atas tiga prinsip dasar (Saaty, 1994), yaitu:

a) Penyusunan Hirarki merupakan langkah untuk mendefinisikan masalah yang rumit dan kompleks, sehingga menjadi jelas dan rinci. Keputusan yang akan diambil ditetapkan sebagai tujuan, yang dijabarkan menjadi elemen-elemen yang lebih rinci hingga mencapai suatu tahapan yang paling operasional/terukur. Hirarki tersebut memudahkan pengambil keputusan untuk memvisualisasikan permasalahan dan faktor-faktor terkendali dari permasalahan tersebut. Hirarki keputusan disusun berdasarkan pandangan dari pihak-pihak yang memiliki keahlian dan pengetahuan di bidang yang bersangkutan.

b) Penentuan Prioritas, Prioritas dari elemen-elemen pada hirarki dapat dipandang sebagai bobot/kontribusi elemen tersebut terhadap tujuan yang ingin dicapai dalam pengambilan keputusan. Metode AHP berdasarkan pada kemampuan dasar manusia untuk memanfaatkan informasi dan pengalamannya untuk memperkirakan pentingnya satu hal dibandingkan dengan hal lain secara relatif melalui proses membandingkan hal-hal berpasangan. Proses inilah yang disebut dengan metode perbandingan berpasangan untuk menganalisis prioritas elemen-elemen dalam hiaraki. Prioritas ditentukan berdasarkan pandangan dan penilaian para ahli dan pihak-pihak yang berkepentingan terhadap pengambilan keputusan, baik dengan diskusi atau kuisioner. 
c) Konsistensi Logika, Prinsip pokok yang menentukan kesesuaian antara definisi konseptual dengan operasional data dan proses pengambilan keputusan adalah konsistensi jawaban dari para responden. Konsistensi tersebut tercermin dari penilaian elemen dari perbandingan berpasangan.

\section{Matrix Perbandingan Berpasangan}

Konsep dasar dari AHP adalah penggunaan pairwise comparison matrix (matriks perbandingan berpasangan) untuk menghasilkan bobot relatif antar kriteria maupun alternatif. Suatu kriteria akan dibandingkan dengan kriteria lainnya dalam hal seberapa penting terhadap pencapaian tujuan di atasnya. Sebagai contoh, kriteria spesifikasi dan kriteria biaya akan dibandingkan seberapa pentingnya dalam hal memilih armada transportasi. Begitu juga untuk alternatif. Kendaraan A, B, dan C akan dibandingkan secara berpasangan (dan akan dibentuk matriks) dalam hal sub-kriteria biaya pemeliharaan misalnya.

Nilai-nilai yang disarankan untuk membuat matriks perbandingan berpasangan adalah sebagai berikut:

- 1 : sama penting (equal)

- 3 : lebih penting sedikit (slightly)

- 5 : lebih penting secara kuat (strongly)

- 7 : lebih penting secara sangat kuat (very strong)

- 9 : lebih penting secara ekstrim (extreme)

Selain nilai-nilai di atas, nilai-nilai antaranya juga bisa digunakan, yakni 2, 4, 6, dan 8 . Nilai-nilai ini menggambarkan hubungan kepentingan di antara nilai-nilai ganjil yang disebutkan di atas. Sementara jika kepentingannya terbalik, maka kita dapat menggunakan angka reprisokal dari nilainilai di atas. Misalnya perbandingan berpasangan antara kriteria 1 dan 3 adalah 1/5, artinya kriteria 3 lebih penting secara kuat dari pada kriteria 1 . Matriks perbandingan berpasangan tersebut harus dibuat tiap level yang memiliki hirarki atasan yang sama. Sebagai contoh pada hirarki sebelumnya, kita harus membuat matriks perbandingan berpasangan untuk sub-kriteria kapasitas angkut dan sub-kriteria ketersediaan suku cadang terhadap kriteria spesifikasi, matriks perbandingan berpasangan antara subkriteria biaya pembelian, biaya pemeliharaan dan biaya perton mileage terhadap kriteria biaya, dan seterusnya.

Cara membuat matriks berpasangan, kita hanya perlu menentukan matriks segitiga atas saja karena matriks segitiga bawah hanyalah nilai reprisokal dari matriks segitiga atas. Selain itu, nilai-nilai diagonal pada matriks perbandingan berpasangan adalah satu (karena setiap item dibandingkan dengan dirinya sendiri). Dengan demikian, apabila kita ingin membuat matriks perbandingan berpasangan dengan jumlah $n$ item, maka kita hanya perlu membuat perbandingan sejumlah $n(n-1) / 2$.

Semua matriks perbandingan berpasangan apabila sudah dikumpulkan, kita dapat menghasilkan bobot prioritas akhir dari kandidat pilihan. Langkah pertama adalah setiap matriks perbandingan berpasangan perlu dicari bobot absolut masing-masing item. Setelah itu, bobot prioritas akhir didapat dengan mengkalikan bobot absolut alternatif dengan bobot-bobot kriteria dan sub-kriteria di atasnya. Kemudian, bobot prioritas akhir ini dapat dijadikan sebagai acuan pemilihan kandidat ataupun pengurutan kepentingan kandidat pilihan.

\section{Kerangka Kerja AHP}

1. Mendefinisikan masalah dan menentukan solusi yang diinginkan.

2. Membuat struktur hirarki yang diawali dengan tujuan umum, dilanjutkan dengan sub tujuan-tujuan, kriteria dan kemungkinan alternative-alternative pada tingkatan kriteria yang paling bawah.

3. Membuat matriks perbandingan berpasangan yang menggambarkan kontribusi relative atau pengaruh setiap elemen terhadap masing-masing tujuan atau kriteria yang setingkat diatasnya. Perbandingan dilakukan berdasarkan judgement dari pengambilan keputusan dengan menilai tingkat kepentingan suatu elemen dibandingkan elemen lainnya.

4. melakukan perbandingan berpasangan sehingga diperoleh judgement seluruh sebanyak $n \times[(n-1) / 2$ ] buah, dengan $n$ adalah banyaknya elemen yang dibandingkan.

5. Menghitung nilai eigen dan menguji konsistensinya, jika tidak konsisten maka pengambilan data diulangi.

6. Mengulangi langkah 3, 4, dan 5 untuk seluruh tingkat hirarki. 
7. Mengikuti vector eigen disetiap matriks perbandingan berpasangan. Nilai vector eigen merupakan bobot setiap elemen. Langkah ini untuk mensistesis judgement dalam penentuan prioritas elemenelemen pada tingkat hirarki terendah sampai pencapaian tujuan.

8. Memeriksa konsistensi hirarki. Jika nilainya lebih dari $10 \%$ maka penilaian data judgement harus diperbaiki.

AHP penyimpangan diperbolehkan dengan toleransi rasio inkonsistensi di bawah 10 persen. Langkah ini dilakukan dengan mengalikan setiap indeks konsistensi dengan prioritas-prioritas kriteria yang bersangkutan dan menjumlahkan hasil kalinya. Hasil ini dibagi dengan pernyataan sejenis yang menggunakan indeks konsistensi acak, yang sesuai dengan dimensi masing-masing matriks. Untuk memperoleh hasil yang baik, rasio inkonsistensi hierarki harus bernilai kurang dari satu atau sama dengan 10 persen. Rasio inkonsistensi diperoleh setelah matriks diolah secara horizontal dengan menggunakan program komputer Expert Choice 2000. Jika rasio inkonsistensi mempunyai nilai yang lebih besar dari 10 persen, maka mutu informasi harus ditinjau kembali dan diperbaiki, antara lain dengan memperbaiki cara menggunakan pertanyaan ketika melakukan pengisian ulang kuesioner dan dengan lebih mengarahkan responden yang mengisi kuesioner.

Metode AHP dalam penelitian ini digunakan untuk menganalisis faktor-faktor yang paling berpengaruh dalam Penanganan Logistik Bencana di Sulawesi Tengah sehingga dapat diketahui strategi yang tepat dalam penanganan logistik bencana guna meminimalisir dampak bencana yang terjadi di Sulawesi Tengah.

\section{METODE PENELITIAN}

Penelitian ini penulis menggunakan tipe penelitian Deskriptif. Tipe penelitian deskriptif adalah desain penelitian yang disusun dalam rangka memberikan gambaran secara sistematis tentang informasi ilmiah yang berasal dari subyek atau objek penelitian. Penelitian ini menggunakan dua jenis data yang dikenal data primer dan data sekunder, baik yang bersifat kualitatif maupun kuantitatif yang berkaitan dengan penelitian ini menjadi sumber data yang dipilih. Jenis Data Menurut Malhotra (2009) terdiri dari data kualitatif dan kuantitatif:

Data Kualitatif adalah yang tidak dinyatakan dalam bentuk angka. Penelitian kualitatif lebih bersifat deskriptif dan data yang terkumpul berbentuk kata-kata atau gambar, sehingga tidak menekankan pada angka. Sehingga dalam penelitian ini, data kualitatif adalah data yang penulis dapatkan dari wawancara ataupun kuisioner yang penulis bagikan yang berupa deskriptif serta penjelasan mengenai penanganan logistik bencana oleh instansi Badan penanggulangan Bencana Daerah (BPBD) Provinsi Sulawesi Tengah dan Dinas Sosial Provinsi Sulawesi Tengah.

Data Kuantitatif dalam bentuk angka-angka dan analisisnya menggunakan alat pengolah angka. Penelitian Kuantitatif lebih bersifat deduktif sehingga data yang terkumpul dalam penelitian ini selanjutnya dianalisis secara kuantitatif dengan menggunakan Microsoft Exel 2007.

Data Primer adalah data yang diperoleh penulis dari hasil pengamatan (observasi) dan wawancara langsung di lapangan dengan para stakeholder yang berkepentingan dalam penanggulangan logistik bencana di Provinsi Sulawesi Tengah. Data Sekunder adalah data yang telah terpublikasi sebelumnya dan didapatkan melalui beberapa literatur dan kepustakaan yang mendukung secara relevan dalam proses penelitian ini.

Adapun teknik-teknik pengumpulan data yang dilakukan dalam penelitian ini adalah sebagai berikut; Observasi, yaitu cara pengumpulan data dengan turun langsung kelapangan untuk mengamati subyek, objek penelitian ataupun kejadian yang dapat memberikan informasi terhadap penelitian ini. Wawancara adalah metode pengumpulan data dengan mengajukan pertanyaan secara lisan kepada sample yang telah ditentukan sebelumnya. Kuesioner, adalah tehnik pengumpulan data dengan cara menyusun pertanyaan yang telah diberi bobot penilaian terhadap setiap jawabannya untuk kemudian dianalisis menggunakan alat dan metode analisis yang telah ditentukan.

Populasi Menurut Malhotra (2009:364) adalah gabungan seluruh elemen, yang memiliki serangkaian karakteristik serupa, yang mencakup semesta untuk kepentingan riset. Berdasarkan teori diatas, maka dapat diketahui populasi dalam penelitian ini adalah semua yang terlibat terhadap penanggulangan logistik bencana di Sulawesi Tengah. Penelitian ini populasinya adalah seluruh pegawai di dinas Badan Peanggulangan Bencana Daerah (BPBD) Provinsi Sulawesi Tengah dan seluruh pegawai Dinas Sosial Provinsi Sulawesi Tengah. 
Sampel adalah sub kelompok elemen populasi yang terpilih untuk berpartisipasi dalam studi (Malhotra, 2009:364). Sampel adalah bagian populasi yang diambil berdasarkan cara-cara tertentu yang mewakili populasi. Penelitian ini yang diambil menjadi sampel adalah Perseorangan yang berdasarkan pertimbangan dan pengamatan sebelumnya . Perseorangan tersebut adalah yang memiliki pengalaman terhadap penanganan logistik bencana dan penentu kebijakan dalam hal penanggulangan logistik bencana di Sulawesi Tengah yang berasal dari Instansi Badan Penanggulangan Bencana Daerah (BPBD) Provinsi Sulawesi Tengah, dan Dinas Sosial Provinsi Sulawesi Tengah.

Tehnik dalam penarikan sampel pada penelitian ini menggunaan tehnik purposive sampling atau judgemental sampling. Hal ini termasuk dalam non-probability sampling, yang artinya dalam tehnik sampling ini tidak menggunakan prosedur pemilihan peluang melainkan menggunakan penilaian pribadi peneliti. Menurut ( Malhotra, 2009) judgemental sampling adalah bentuk sampling convenience yang didalam elemen populasi dipilih secara positif berdasarkan judgement peneliti dengan catatan bahwa sampel tersebut representatif atau mewakili populasi, serta pemilihannya didasarkan atas ciri-ciri atau sifat-sifat tertentu yang dipandang sesuai. Adapun kriteria-kriteria responden yang dijadikan sampel dalam penelitian ini; (1) Pernah terlibat atau menangani masalah logistik bencana di Sulawesi Tengah minimal selama satu periode atau 5 (lima) tahun. (2) Merupakan Pengambil kebijakan dalam penanggulangan logistik Bencana di Sulawesi Tengah. (3)Mengetahui permasalahan secara mendalam yang berkaitan dengan penanganan logistik bencana di Sulawesi Tengah.

Data yang telah terkumpul nantinya akan diolah menggunanakan alat analisis data Microsoft Office Exel 2007. Teknik Analisis yang digunakan dalam penelitian ini adalah Tehnik Proses Hirarki Analisis (PHA) yang bertujuan untuk melihat sejauh mana penilaian responden terhadap hal-hal yang mempengaruhi pelaksanaan penanggulangan bencana di Propinsi Sulawesi Tengah.

\section{PEMBAHASAN HASIL PENELITIAN}

\section{Uji Konsistensi}

Uji konsistensi merupakan Prasyarat utama untuk menilai apakah responden konsisten dalam memberikan jawaban dari setiap respon yang ada dalam kuesioner. Model AHP yang memakai persepsi manusia sebagai input utamanya ini, maka ketidak konsistenan mungkin saja akan terjadi karena manusia memiliki keterbatasan dalam menyatakan persepsinya secara konsisten apa lagi kalau harus membandingkan dengan banyak kriteria. Berdasarkan hal ini maka Uji Konsistensi ini dipandang sangat penting untuk menghasilkan jawaban yang diharapkan. Pengukuran konsisten ini dimaksudkan untuk melihat ketidak konsistenan dari respon yang diberikan responden. Jika CR $<0,1$ maka nilai perbandingan berpasangan pada matriks kriteria yang diberikan konsisten. Namun jika CR $>0,1$ maka nilai perbandingan berpasangan pada matriks kriteria yang diberikan tidak konsisten. Sehingga jika tidak konsisten, maka pengisian nilai-nilai pada matriks berpasangan pada elemen Tujuan maupun elemen fokus harus diulangi. Tabel berikut ini menunjukan nilai konsistensi rasio (CR) dari Penilaian responden:

Tabel 1

Konsistensi Rasio (CR) Penilaian Responden

\begin{tabular}{|l|c|l|}
\hline \multicolumn{1}{|c|}{ Perbandingan Berpasangan } & CR & Keterangan \\
\hline Antar elemen Kriteria (level 1) & 0,09 & Konsisten \\
\hline Antar fokus SDM & 0,02 & Konsisten \\
\hline Antar fokus Situasi Ketidakpastian & 0,00 & Konsisten \\
\hline Antar fokus Kolaborasi dan kerjasama & 0,00 & Konsisten \\
\hline Antar fokus Sarana dan Prasarana & 0,08 & Konsisten \\
\hline Antar fokus Pendanaan & 0,00 & Konsisten \\
\hline
\end{tabular}

Sumber: Hasil Pengolahan AHP

\section{Memilih Prioritas Pengendalian Logistik Bencana}

Masing-masing nilai dari elemen Tujuan maupun fokus didapatkan kemudian dilakukan sintesis untuk mendapatkan bobot prioritas secara keseluruhan dari kriteria yang ada. Sebelumnya bobot/prioritas lokal harus dicari nilai globalnya dengan cara mengalikan prioritas lokal dengan 
prioritas level diatasnya. Prioritas global ini dilakukan setelah metriks pendapat memenuhi persyaratan rasio inkonsistensi. Secara detail, hasil pembobotan Tujuan dan faktor dapat dilihat pada tabel berikut:

Tabel 2

Prioritas Global (Global Priority)

\begin{tabular}{|c|c|c|c|c|c|c|}
\hline FOKUS & Kriteria & $\begin{array}{c}\text { Local } \\
\text { Wigh } \\
\mathbf{t}\end{array}$ & $\begin{array}{c}\text { Sub- } \\
\text { Kriteria }\end{array}$ & $\begin{array}{c}\text { Local } \\
\text { Weight }\end{array}$ & $\begin{array}{l}\text { Global } \\
\text { Weight }\end{array}$ & Prioritas \\
\hline \multirow{13}{*}{$\begin{array}{c}\text { Penentuan Prioritas } \\
\text { Pengendalian logistik } \\
\text { Bencana }\end{array}$} & \multirow{3}{*}{$\begin{array}{c}\text { Sumber } \\
\text { Daya Manusi }\end{array}$} & \multirow{3}{*}{0.6} & Plt & 0.81 & 0.486 & \multirow{3}{*}{ I } \\
\hline & & & Inf & 0.07 & 0.042 & \\
\hline & & & Mki & 0.12 & 0.072 & \\
\hline & \multirow{2}{*}{$\begin{array}{c}\text { Situasi } \\
\text { Ketidakpasti } \\
\text { an }\end{array}$} & \multirow[b]{2}{*}{0.05} & Cuac & 0.88 & 0.044 & \multirow[b]{2}{*}{ IV } \\
\hline & & & Kea & 0.13 & 0.0065 & \\
\hline & \multirow{2}{*}{$\begin{array}{c}\text { Kolaborasi } \\
\text { dan } \\
\text { Kerjasama }\end{array}$} & \multirow{2}{*}{0.09} & Kpe & 0.13 & 0.0117 & \multirow{2}{*}{ III } \\
\hline & & & Kepp & 0.88 & 0.0792 & \\
\hline & \multirow{4}{*}{$\begin{array}{c}\text { Sarana } \\
\text { Prasarana }\end{array}$} & \multirow{4}{*}{0.23} & TIK & 0.67 & 0.1541 & \multirow{4}{*}{ II } \\
\hline & & & Fprg & 0.05 & 0.0115 & \\
\hline & & & Fppl & 0.21 & 0.0483 & \\
\hline & & & Altp & 0.08 & 0.0184 & \\
\hline & \multirow{2}{*}{ Pendanaan } & \multirow{2}{*}{0.04} & $\mathrm{Pt}$ & 0.875 & 0.035 & \multirow{2}{*}{ V } \\
\hline & & & PPd & 0.125 & 0.005 & \\
\hline
\end{tabular}

Sumber: Hasil Pengolahan AHP(Lampiran II)

Berdasarkan Tabel 2 diatas menunjukan bahwa dalam menentukan prioritas logistik bencana di Sulawesi Tengah, diketahui bahwa Sumber Daya Manusia adalah faktor utama dengan bobot 0,6. Menurut Abdurrahmat Fathoni (2006) Sumber Daya Manusia merupakan modal dan kekayaan yang terpenting dari setiap kegiatan manusia. Manusia sebagai unsur terpenting mutlak dianalisis dan dikembangkan dengan cara tersebut.

Berdasarkan pendapat Abdurahman Fathoni tersebut dapat disimpulkan bahwa Sumber Daya Manusia sangatlah penting bagi Penanganan dalam kegiatan apapun yang masih melibatkan manusia didalamnya, tanpa terkecuali Penanganan logisitik bencana, sumber daya manusia menjadi faktor utama. Sumber daya manusia menjadi sangat penting karena dalam setiap aktivitas penanganan logistik bencana manusia akan selalu terlibat baik dari tahap perencanaan, pengumpulan bahkan sampai dengan penyaluran dan penanganan korban sebelum maupun sesudah terjadinya bencana. Faktor utama yang sangat mempengaruhi kualitas sumber daya manusia dalam penanganan logistik bencana di Sulawesi Tengah adalah pelatihan, sebab dengan pelatihan kualitas sumber daya manusia dapat ditingkatkan sehingga dapat dengan mudah melakukan penanganan baik sebelum maupun sesudah terjadinya bencana. Selama ini berdasarkan keterangan responden, pelatihan untuk meningkatkan kualitas sumber daya manusia masih sangat kurang diadakan, kalaupun ada biasanya tidak berkelanjutan.

Prioritas ke dua dalam penanganan logistic bencana di Sulawesi tengah adalah Sarana Prasaran. Dengan nilai bobot 0,23 sarana prasarana menjadi faktor penunjang terpenting dalam setiap kegiatan logistik bencana. Terutama Teknologi Komunikasi dan Informasi (TIK) adalah hal yang sangat penting dimiliki oleh setiap tim penanganan bencana. Tanpa adanya Teknologi Informasi dan Komunikasi yang baik Kebutuhan korban bencana tidak bisa diindentifikasi dengan baik serta penanganan akan korban bencana bisa menjadi lebih lambat. Di Sulawesi tengah sendiri terkhusus pada Instansi Badan Penanggulangan Bencana Daerah (BPBD) Provinsi Sulawesi Tengah dan Dinas Sosial Provinsi Sulawesi Tengah, teknologi informasi dan komunikasi sudah cukup memadai, hanya saja biasanya akses jalan menuju lokasi bencana banyak yang terisolir akibatnya dibutuhkan beberapa hari untuk membuka jalan menuju lokasi bencana. 
Prioritas selanjutnya adalah Kolaborasi dan kerja sama dengan nilai bobot 0,09, dimana dalam penanganan kebencanaan kerjasama dan kolaborasi sangat berperan penting guna menolong korban bencana secara efektif dan efisien. Faktor kepemimpinan sangat berperan penting. Kepemimpinan yang baik maka kolaborasi dan kerja sama antara semua tim yang ada dapat berjalan dengan efektif dan efisien. Semua penanganan baik pemberian bantuan, pertolongan pertama, maupun pengobatan paska bencana dapat ditangani dengan baik. Penerapannya di sulawesi tengah dinas terkait dalam hal ini BBPD dan Dinas Sosial Sulawesi Tengah biasanya berkolaborasi jika sudah dilapangan, dimana dinas sosial berperan menangani konsumsi korban seperti makan, minum, dan sanitasi, sementara BPBD berperan melakukan efakuasi korban bencana.

Faktor Situasi ketidakpastian juga perlu mendapat perhatian lebih dalam penanganan logistik bencana di Sulawesi Tengah, dalam tabel diatas ditunjukan bahwa faktor ini menempati urutan keempat dengan nilai bobot 0,05. Pada faktor situasi yang tidak pasti ini Cuaca adalah hal yang sangat perlu diperhatikan. Dimana dalam penanganan logistik bencana Tim Reaksi Cepat (TRC) ataupun timtim lainnya yang menangani korban bencana mendapat kendala dari cuaca yang tidak menentu, kalau tidak dibekali dengan sumber daya manusia yang baik maupun kelengkapan pertolongan lainnya bisa jadi korban akan lambat ditangani.

Pada prioritas terakhir adalah factor pendanaan, dimana dengan nilai bobot 0,04 pendanaan juga merupakan factor penunjang dalam penangan logistic bencana.

\section{KESIMPULAN DAN SARAN \\ Kesimpulan \\ Hasil Penentuan Prioritas}

Kelima faktor yang mempengaruhi Penerapan Manajemen Logistik Bencana di Sulawesi Tengah yakni, Sumber Daya Manusia (SDM), Situasi Ketidakpastian, Kolaborasi dan Kerjasama, Sarana Prasarana, dan Pendanaan faktor Sumber Daya Manusia adalah Prioritas Utama dalam Penangan Logistik bencana di Sulawesi Tengah dimana pelatihan adalah sub kriteria yang paling berpengaruh terhadap peningkatan Kualitas Sumber Daya Manusia.

\section{Urutan Prioritas berdasarkan Hasil Perhitungan}

Hasil perhitungan kelima faktor yang mempengaruhi Penerapan Manajemen Logistik Bencana di Sulawesi Tengah, Sumber Daya Manusia adalah prioritas Utama dengan bobot hitung 0,59, selanjutnya adalah Sarana Prasarana dengan bobot 0,22. Di urutan ketiga Kolaborasi dan Kerjasama berbobot 0,08 kemudian disusul Situasi Ketidak Pastian dan Pendanaan dengan Bobot masing-masing 0,05 dan 0,03 .

\section{Saran}

Hasil analisis yang telah dibahas dan kesimpulan yang telah dipaparkan, peneliti menyarankan agar instansi terkait dalam hal ini BPBD Provinsi Sulawesi Tengah dan Dinas Sosial Provinsi Sulawesi tengah harus mengadakan pelatihan yang berkelanjutan agar dapat meningkatkat Kualitas Sumber Daya Manusia anggotanya guna tercapainya efektifitas dan efisiensi dalam penanganan Logistik Bencana Di Provinsi Sulawesi Tengah.

\section{REFERENSI}

Abdurahmat, Fathoni. (2006). Manajemen Sumber Daya Manusia. Jakarta: PT. Rineka Cipta. Altay, Nezih., \& Green. (2006). Research in disaster operations management. European Journal of Operational Research, 175, 475-493.

Amir, Taufik. (2005). Dinamika Pemasaran:Jelajahi dan Rasakan. Jakarta: PT. Rajagrafindo Persada. BPBN.2012.Badan Penanggulangan Bencana Nasional (BPBN). Diakses dari: http://www.bnpb.go.id/. (10 Agustus 2016)

Dwiantara, Lukas \& Sumarto, Hadi, Rumsari. (2004). Manajemen Logistik. Jakarta: Grasindo.

Malhotra, N.K., (2009). Riset Pemasaran. Jakarta: PT Indeks.

Mulyono, Agus., Indriyo. (2000). Manajemen Bisnis Logistik. Yogyakarta: BPFE-YOGYAKARTA. 
Oktarina, Rienna. (2009). Konseptual Perencanaan Sistem Informasi Manajemen Logistik Penanggulangan Bencana (SIMLOG-PB) berbasis GIS (Geographic Information System). Seminar Nasional Aplikasi Teknologi Informasi, ISSN:1907-5022.

Pettit, S., \& Beresford, A. (2009). Critical success factors in the context of humanitarian aid supply chains. International Journal of Physical Distribution \& Logistics Management, 39, 450-468.

Saaty, T. L. (1980). The analytic hierarchy process, New York: McGraw-Hill.

Saaty, T. L. (1994). Highlights and critical points in the theory and application of the analytic hierarchy process. European Journal of Operational Research, 74, 426-427.

Stock, James R., \& Douglas M. Lambert. (2001). Strategic Logistics Management;fourth edition. New York: McGRAW-HILL.

Subagya, MS. (1996). Manajemen Logistik. Jakarta: Haji Masagung.

Undang-undang Republik Indonesia No. 24 tahun 2007, Tentang Penanggulangan Bencana.

Van Wassenhove, L. (2006). Humanitarian aid logistics: supply chain management in high gear.

Journal of the Operational Research Society, 57, 475-489. 